Research paper

\title{
Application of micro-PIXE (particle induced X-ray emission) to study buckwheat grain structure and composition
}

\author{
Paula PONGRAC ${ }^{1, *}$, Mitja KELEMEN ${ }^{1}$, Primož VAVPETIČ ${ }^{1}$, Katarina VOGEL-MIKUŠ $\check{S}^{1,2}$, \\ Marjana REGVAR ${ }^{2}$, Primož PELICON ${ }^{1}$ \\ 1 Jožef Stefan Institute, Jamova 39, 1000 Ljubljana, Slovenia \\ 2 Biotechnical Faculty, University of Ljubljana, Jamnikarjeva 101, 1000 Ljubljana, Slovenia \\ * Corresponding author: \\ Jožef Stefan Institute, Jamova 39, 1000 Ljubljana, Slovenia \\ Tel: +38651222963 . \\ E-mail addresses: paula.pongrac@ijs.si; mitja.kelemen@ijs.si; primoz.vavpetic@ijs.si; katarina.vogelmikus@bf.uni-lj.si; \\ marjana.regvar@bf.uni-lj.si; primoz.pelicon@ijs.si
}

DOI https://doi.org/10.3986/fag0012

Received: April 18, 2020; accepted: May 6, 2020

Keywords: Tartary buckwheat, micro-PIXE, elements, calcium, magnesium, phosphorus, sulphur, embryo, grain tissues, spatial distribution

\begin{abstract}
Tartary buckwheat (Fagopyrum tataricum Gaertn.) is a gluten-free pseudo-cereal crop with a grain nutrient profile that makes it an excellent alternative foodstuff. The distribution of calcium ( $\mathrm{Ca}$ ), magnesium ( $\mathrm{Mg}$ ), phosphorus (P) and sulphur (S) was investigated by micro-PIXE (particle induced X-ray emission) to resolve allocation and concentration of the elements in nine distinct grain tissues. Magnesium, $\mathrm{P}$ and $\mathrm{S}$ were preferentially allocated to the cotyledons and the embryonic axis (both inner and outer tissues), and $\mathrm{Ca}$ was predominant in the pericarp where two Ca-rich layers were observed. Allocation of $\mathrm{P}$ and $\mathrm{S}$ to aleurone suggests that this layer of cells, although not as prominent as in cereal grain, is rich in phytate and proteins. Quantitative information on spatial distribution of mineral elements in the edible grain may be useful in the technological processing of the grain and particularly in reducing the amount of mineral-element loss during milling.
\end{abstract}


Pongrac et al. (2020): Application of micro-PIXE to study buckwheat grain

\section{INTRODUCTION}

Over four decades ago, an interdisciplinary research team comprising scientists from the Jožef Stefan Institute and the Biotechnical Faculty, University of Ljubljana began a fruitful collaboration with the aim to study elemental composition of edible crop tissues, in particular the presence of $S$ in protein-rich seeds (Budnar et al., 1980; Kump et al., 1977, 1976; Rupnik et al., 1977). Among other goals, they planned to employ a recently developed technique, the particle induced $\mathrm{X}$-ray emission (PIXE), which enables a quantitative analysis of biologically relevant elements in plant tissue. The technique was at its infancy and two main obstacles prevented significant progress: i) the size of the analytical beam (in millimetre range) exceeded the size of the regions of interest several-fold and ii) the energy range of the beam was inappropriate, leading to irreparable radiation damage to biological samples. Eventually, the beamline was equipped with magnetic lenses to focus the ion beam into the micrometre scanning resolution (micro-PIXE), following the elegant original demonstration on wheat (Triticum aestivum L.) grain (Mazzolini et al., 1985). Along with that the beam energy profile was optimized. First high-quality element distribution maps were acquired almost thirty years after the discouraging initial attempts. The case study was common buckwheat (Fagopyrum esculentum Moench) grain (Vogel-Mikuš et al., 2009), followed by the analysis with improved lateral resolution (Pongrac et al., 2011). The detailed element distributions in Tartary buckwheat grain corroborated observations in common buckwheat grain in which the largest concentrations of $\mathrm{Mg}, \mathrm{P}, \mathrm{S}$, potassium (K), iron $(\mathrm{Fe})$ and zinc $(\mathrm{Zn})$ were found in cotyledons and that of $\mathrm{Ca}$ in pericarp (Pongrac et al., 2013a). By contrast, 7-day-old cotyledons of Tartary buckwheat sprout relocated Ca to inter-vascular mesophyll, $\mathrm{Mg}$ to mesophyll and $\mathrm{S}$ to epidermis (Pongrac et al., 2016a). The described progress was accompanied using complementary techniques such as scanning electron microscopy and fluorescence microscopy (Francisco and Kreft, 1989; Javornik and Kreft, 1980; Kreft and Kreft, 2000) and synchrotron radiation micro X-ray fluorescence mapping (Pongrac et al., 2013a; 2016b; 2016c; 2017). This short review emphasises tissue-specific allocation of $\mathrm{Ca}, \mathrm{Mg}, \mathrm{P}$ and $S$ in Tartary buckwheat grain and specifically focuses on elemental composition of aleurone and embryonic axis.

\section{MATERIALS AND METHODS}

Tartary buckwheat grain was provided by a local grower (cultivar 'Zlata', Mlin Rangus, Dolenje Vrhpolje at Šentjernej, Slovenia) in 2018. The grain was soaked for $4 \mathrm{~h}$ in Milli-Q water at $4^{\circ} \mathrm{C}$, hand-cut into 2-mm-thick cross-sections (perpendicular to the embryonic axis) with a sharp stainless-steel platinum-coated razor blade, frozen in liquid nitrogen and freeze dried for 2 days at $-24^{\circ} \mathrm{C}$ and $0.120 \mathrm{mbar}$. The hand-cut dried sections were mounted between two layers of Pioloform foil stretched over aluminium frames (Vogel-Mikuš et al., 2009, 2014). The spatial distribution of the mineral elements was determined using micro-PIXE set-up of the Jožef Stefan Institute, Slovenia, as described previously (Lyubenova et al., 2012; Pongrac et al., 2013b). The quantitative mineral element distribution maps were generated using the GEOPIXE II software package (Ryan, 2000) and tissue-specific concentrations were extracted from the numerical matrices obtained with the GEOPIXEII software, using the ImageJ programme (Abràmoff et al., 2004).

\section{RESULTS AND DISCUSSION}

Quantitative distribution maps of $\mathrm{Ca}, \mathrm{Mg}, \mathrm{P}$ and $\mathrm{S}$ in Tartary buckwheat grain are shown in Fig. $\mathbf{1}$.

Allocation of $\mathrm{Ca}$ to pericarp (Fig. 1A), where two distinct Ca-rich layers (one in inner pericarp and another in outer pericarp) were observed in agreement with previous observations in common buckwheat (Pongrac et al., 2011; Vogel-Mikuš et al., 2009) and other crops: different cereal grain (Antonini et al., 2018; Pongrac et al., 2013c; Ren et al., 2007; Singh et al., 2014) and legume seed (Cominelli et al., 2020). A poor mobility of $\mathrm{Ca}$ in phloem (White and Broadley, 2003) and consequently the limited translocation of Ca from maternal (pericarp) to filial (embryo and endosperm) grain tissues may explain this observation. On average 3,000 $\mathrm{mg} \mathrm{Ca} \mathrm{kg}^{-1}$ was found in pericarp, which was 20 times more than in endosperm and 4 times more than in cotyledons (Fig. 2).

Calcium is the only element to exhibit such distinct allocation to pericarp (Fig. 1). Magnesium is allocated to cotyledons and embryonic axis, with some $\mathrm{Mg}$ found also in the outer layer of pericarp (Fig. 1B). In pericarp the average $\mathrm{Mg}$ concentration was 4 times smaller than in cotyledons (8,600 $\mathrm{mg} \mathrm{kg}^{-1}$ dry weight); and in endosperm 4 times smaller (Fig. 2). Phosphorus is clearly allocated to cotyledons and the embryonic axis (Fig. 1C). The largest $\mathrm{P}$ concentration is found in the outer layer of embryonic axis 


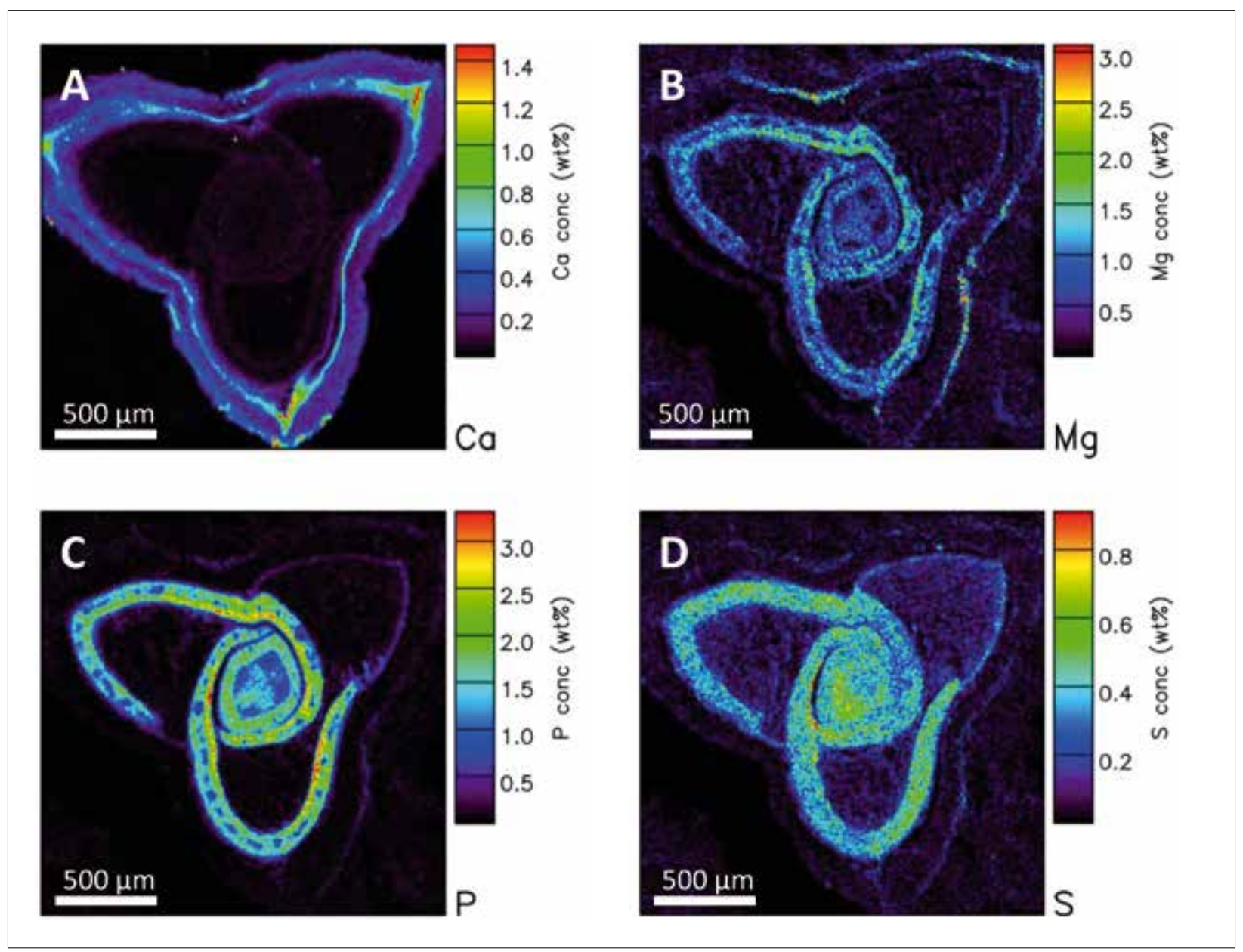

Figure 1 Quantitative mineral-element distribution maps in a representative Tartary buckwheat (Fagopyrum tataricum) grain crosssection, comprising a centrally-positioned embryonic axis, a pair of cotyledons surrounding the endosperm and the pericarp. Distribution map of calcium (Ca; A), magnesium (Mg; B), phosphorus (P; C) and sulphur (S; D). The colour scales are in weight \%.

(Fig. 2). Phosphorus distribution can be used as an approximation of the location of phytate, a salt of phytic acid which strongly binds (even immobilizes) some essential mineral elements (mainly the divalent cations), such as $\mathrm{Mg}$, manganese, (Mn), Fe and $\mathrm{Zn}$ in grain and seed (Hallberg et al., 1987; Pongrac et al., 2013a; Regvar et al., 2011). The co-localisation of Mg and P in Fig. 1 illustrates the fact. During germination these mineral elements are being enzymatically released to become available for the growth of the seedling. Endosperm and pericarp contain around 30-times less $\mathrm{P}$ per unit mass than the embryo (Fig. 2). Sulphur, on the other hand, can be used as an indicator of proteins (Budnar et al., 1980; Kump et al., 1976), being present in two common amino acids, methionine and cysteine. In wheat grain, $S$ was mainly locat- ed in sub-aleurone layer reflecting a significant presence of proteins in these cells (Pongrac et al., 2013c; Singh et al., 2014; Tosi et al., 2009), whereas in Tatary buckwheat grain, $S$ is allocated mainly, to cotyledons and the embryonic axis (Fig. 1D; (Pongrac et al., 2013a)). However, there is a thin layer enriched in $\mathrm{Mg}, \mathrm{S}$ and $\mathrm{P}$ just under the pericarp, surrounding the endosperm. This is aleurone, which is in contrast to cereal grain, a layer of small cells (approximately 10-15 $\mu \mathrm{m}$ in thickness) in buckwheat grain (Javornik and Kreft, 1980). Because aleurone of buckwheat grain is so inconspicuous (often strongly attached to the cotyledons) it is seldom mentioned, although it has been previously noticed in common buckwheat (Vogel-Mikuš et al., 2009). In buckwheat grain the aleurone is known to contain large concentration of pro- 


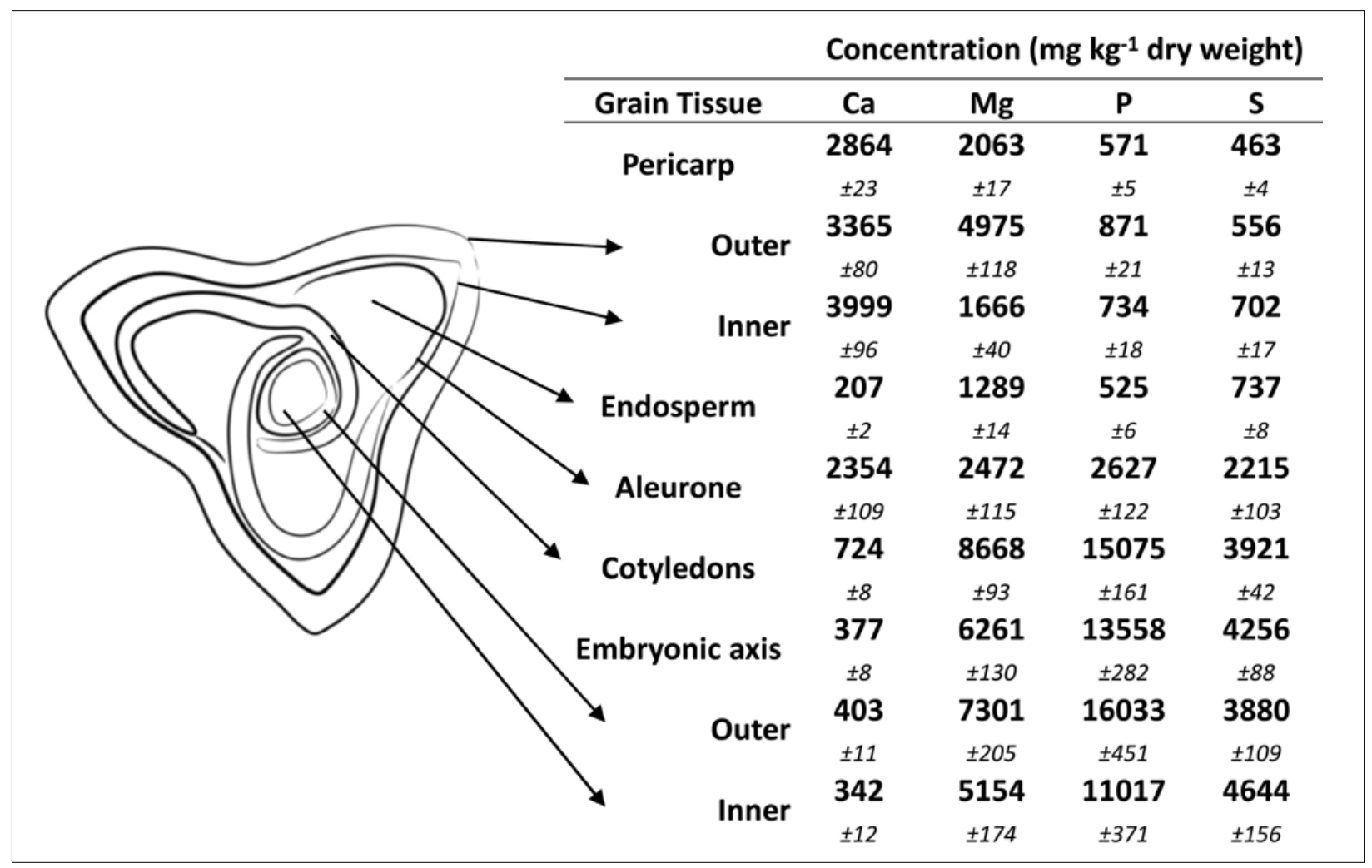

Figure 2 A schematic picture of the Tatary buckwheat (Fagopyrum tataricum) grain cross-section and corresponding average concentration ( $m g \mathrm{~kg}^{-1}$ dry weight; in bold) with standard error of measurement (in italics) for calcium ( $\mathrm{Ca}$ ), magnesium (Mg), phosphorus (P) and sulphur $(S)$ as extracted from the distribution maps.

teins, as also supported by the $\mathrm{S}$ distribution maps shown here.

For optimum evaluation of nutritional quality of buckwheat grain the elemental distribution maps should be complemented with distributions of secondary metabolites as accessible with $\mathrm{MeV}$ secondary ion mass spectrometry, currently being developed at the nuclear microprobe at the Jožef Stefan Institute. Because buckwheat grain contains large concentrations of rutin and quercetin (Fabjan et al., 2003), antioxidants exhibiting positive impact on human health, understanding their allocation will have important consequences in planning milling fractions and further grain processing.

\section{CONCLUSIONS}

Results demonstrate that in Tartary buckwheat grain $\mathrm{Mg}, \mathrm{P}$ and $\mathrm{S}$, are preferentially allocated to the cotyledons and the embryonic axis (both inner and outer tissues), while Ca presence is predominant in the pericarp, where two Ca-rich layers can be observed. Phosphorus and S distributions can be used as indicators for phytate and protein distribution, respectively. Understanding the quantitative distribution of mineral elements is essential for the technological processing of the grain, with an impact on the amount of mineral-element loss during milling.

\section{ACKNOWLEDGEMENTS}

This study was financed by the Slovenian Research Agency, through programmes P1-0143, P1-0212, P10112 and I0-0005, basic projects (N7-0077, J7-9418, J7-9398, N1-0105 and N1-0090) and the applied project L4-9305, co-financed by the Ministry of Agriculture, Forestry and Food, Republic of Slovenia. The funding organizations had no role in the design, analysis or writing of this article. The authors are grateful to Prof. Alojz Kodre for reading early version of the manuscript and for his English editing. 
Fagopyrum 37(1):5-10 (2020)

\section{REFERENCES}

Abràmoff, M. D., P. J. Magalhães, and R. J. Sunanda, 2004. Image processing with ImageJ. Biophotonics Int. 11, 36-42.

Antonini, E., C. Zara, L. Valentini, P. Gobbi, P. Ninfali, and M. Menotta, 2018. Novel insights into pericarp, protein body globoids of aleurone layer, starchy granules of three cereals gained using atomic force microscopy and environmental scanning electronic microscopy. Eur. J. Histochem. 62. https://doi.org/10.4081/ejh.2018.2869

Budnar, M., P. Kump, and I. Kreft, 1980. Uporaba protonsko vzbujene fluorescence žarkov X (PIXE) za določanje koncentracij mikroelementov v tleh in rastlinah. Agrohemija 1-2, 17-19.

Cominelli, E., M. Galimberti, P. Pongrac, M. Landoni, A. Losa, D. Paolo, M. G. Daminati, R. Bollini, K. A. Cichy, K. Vogel-Mikuš, and F. Sparvoli, 2020. Calcium redistribution contributes to the hard-to-cook phenotype and increases PHA-L lectin thermal stability in common bean low phytic acid 1 mutant seeds. Food Chem. 321, 126680. https://doi.org/10.1016/j.foodchem.2020.126680

Fabjan, N., J. Rode, I. J. Košir, Z. Wang, Z., Z. Zhang, and I. Kreft, 2003. Tartary buckwheat (Fagopyrum tataricum Gaertn.) as a source of dietary rutin and quercitrin. J. Agric. Food Chem. 51, 6452-6455. https://doi.org/10.1021/ jf034543e

Francisco, A. De and I. Kreft, 1989. Morphological studies on the location and size of the buckwheat embryo. FAGOPYRUM 9, 47-48.

Hallberg, L., L. Rossander, and A. B. Skånberg, 1987. Phytates and the inhibitory effect of bran on iron absorption in man. Am. J. Clin. Nutr. 45, 988-996. https://doi.org/10.1093/ajcn/45.5.988

Javornik, B., and I. Kreft, 1980. Structure of buckwheat kernel, in: Buckwheat, IBRA. pp. 105-110.

Kreft, S., and M. Kreft, 2000. Localization and morphology of the buckwheat embryo. FAGOPYRUM 17, 15-19.

Kump, P., P. Rupnik, M. Budnar, and I. Kreft, 1977. Analysis of sulphur in plant material. Nucl. Instruments Methods 142, 205-208. https://doi.org/https://doi.org/10.1016/0029-554X(77)90829-1

Kump, P., P. Rupnik, and I. Kreft, 1976. Development of a physical screening method for high methionine and high cystine mutants. Genetika 8, 137-142.

Lyubenova, L., P. Pongrac, K. Vogel-Mikuš, G. Kukec Mezek, P. Vavpetič, N. Grlj, P. Kump, M. Nečemer, M. Regvar, P. Pelicon, and P. Schröder, 2012. Localization and quantification of Pb and nutrients in Typha latifolia by micro-PIXE. Metallomics 4, 333-341. https://doi.org/10.1039/c2mt00179a

Mazzolini, A. P., C. K. Pallaghy, and G. J. F. Legge, 1985. Quantitative microanalysis of Mn, Zn and other elements in mature wheat seed. New Phytol. 100, 483-509. https://doi.org/10.1111/j.1469-8137.1985.tb02796.x

Pongrac, P, I. Kreft, K. Vogel-Mikuš, M. Regvar, M. Germ, P. Vavpetič, N. Grlj, L. Jeromel, D. Eichert, B. Budič, and P. Pelicon, 2013b. Relevance for food sciences of quantitative spatially resolved element profile investigations in wheat (Triticum aestivum) grain. J. R. Soc. Interface 10. https://doi.org/10.1098/rsif.2013.0296

Pongrac, P., P. Kump, B Budič, and K. Vogel-Mikuš, 2017. Magnesium and phosphorus distributions in developing Tartary buckwheat cotyledons. Folia Biol. Geol. 57, 45. https://doi.org/10.3986/fbg0011

Pongrac, P., M. Potisek, A. Fraś, M. Likar, B. Budič, K. Myszka, D. Boros, M. Nečemer, M. Kelemen, P. Vavpetič, P. Pelicon, K. Vogel-Mikuš, M. Regvar, and I. Kreft, 2016a. Composition of mineral elements and bioactive compounds in tartary buckwheat and wheat sprouts as affected by natural mineral-rich water. J. Cereal Sci. 69, 9-16. https://doi. org/10.1016/j.jcs.2016.02.002

Pongrac, P., N. Scheers, S. Sandberg, M. Potisek, I. Arčon, I. Kreft, P. Kump, and K. Vogel-Mikuš, 2016b. The effects of hydrothermal processing and germination on Fe speciation and Fe bioaccessibility to human intestinal Caco-2 cells in Tartary buckwheat. Food Chem. 199, 782-790. https://doi.org/10.1016/j.foodchem.2015.12.071

Pongrac, P., K. Vogel-Mikuš, L. Jeromel, P. Vavpetič, P. Pelicon, B. Kaulich, A. Gianoncelli, D. Eichert, M. Regvar, and I. Kreft, 2013a. Spatially resolved distributions of the mineral elements in the grain of tartary buckwheat (Fagopyrum tataricum). Food Res. Int. 54, 125-131. https://doi.org/10.1016/j.foodres.2013.06.020

Pongrac, P., K. Vogel-Mikuš, M. Potisek, E. Kovačec, B. Budič, P. Kump, M. Regvar, and I. Kreft, 2016c. Mineral and trace element composition and importance for nutritional value of buckwheat grain, groats, and sprouts, in: Molecular Breeding and Nutritional Aspects of Buckwheat. Elsevier, pp. 261-271. https://doi.org/10.1016/B978-0-12-8036921.00020-1 
Pongrac et al. (2020): Application of micro-PIXE to study buckwheat grain

Pongrac, P., K. Vogel-Mikuš, M. Regvar, M. Kaligarič, P. Vavpetič, M. Kelemen, N. Grlj, O. Shelef, A. Golan-Goldhirsh, S. Rachmilevitch, and P. Pelicon, 2013c. On the distribution and evaluation of $\mathrm{Na}, \mathrm{Mg}$ and $\mathrm{Cl}$ in leaves of selected halophytes. Nucl. Instruments Methods Phys. Res. Sect. B Beam Interact. with Mater. Atoms 306, 144-149. https://doi.org/10.1016/j.nimb.2012.12.057

Pongrac, P., K. Vogel-Mikuš, M. Regvar, P. Vavpetič, P. Pelicon, and I. Kreft, 2011. Improved lateral discrimination in screening the elemental composition of buckwheat grain by micro-PIXE. J. Agric. Food Chem. 59, 1275-1280. https://doi.org/10.1021/jf103150d

Regvar, M., D. Eichert, B. Kaulich, A. Gianoncelli, P. Pongrac, K. Vogel-Mikuš, and I. Kreft, 2011. New insights into globoids of protein storage vacuoles in wheat aleurone using synchrotron soft X-ray microscopy. J. Exp. Bot. 62. https://doi.org/10.1093/jxb/err090

Ren, X.-L., Q.-L. Liu, H.-W. Fu, D. Wu, and Q.-Y. Shu, 2007. Density alteration of nutrient elements in rice grains of a low phytate mutant. Food Chem. 102, 1400-1406. https://doi.org/10.1016/j.foodchem.2006.05.065

Rupnik, P., P. Kump, M. Budnar, and I. Kreft, 1977. Protein quality of leguminous plants determined by proton-induced radiation analysis. Nucl. Instruments Methods 142, 209-211. https://doi.org/https://doi.org/10.1016/0029554X(77)90830-8

Ryan, C. G., 2000. Quantitative trace element imaging using PIXE and the nuclear microprobe. Int. J. Imaging Syst. Technol. 11, 219-230. https://doi.org/10.1002/ima.1007

Singh, S. P., K. Vogel-Mikuš, P. Vavpetič, L. Jeromel, P. Pelicon, J. Kumar, and R. Tuli, 2014. Spatial X-ray fluorescence micro-imaging of minerals in grain tissues of wheat and related genotypes. Planta 240, 277-289. https://doi.org/10.1007/s00425-014-2084-4

Tosi, P., M. Parker, C. S. Gritsch, R. Carzaniga, B. Martin, P. R. Shewry, 2009. Trafficking of storage proteins in developing grain of wheat. J. Exp. Bot. 60, 979-991. https://doi.org/10.1093/jxb/ern346

Vogel-Mikuš, K., P. Pongrac, and P. Pelicon, 2014. Micro-PIXE elemental mapping for ionome studies of crop plants. Int. J. PIXE 24, 217-233. https://doi.org/10.1142/S0129083514400142

Vogel-Mikuš, K., P. Pongrac, P. Pelicon, P. Vavpetič, B. Povh, H. Bothe, and M. Regvar, 2009. Micro-PIXE analysis for localization and quantification of elements in roots of mycorrhizal metal-tolerant plants, in: Varma, A., Kharkwal, A.C. (Eds.), Symbiotic Fungi: Principles and Practice. Springer Berlin Heidelberg, Berlin, Heidelberg, pp. 227-242. https://doi.org/10.1007/978-3-540-95894-9_14

Vogel-Mikuš, K., P. Pelicon, P. Vavpetič, I. Kreft, and M. Regvar, 2009. Elemental analysis of edible grains by micro-PIXE: Common buckwheat case study. Nucl. Instruments Methods Phys. Res. Sect. B Beam Interact. with Mater. Atoms 267, 2884-2889. https://doi.org/10.1016/j.nimb.2009.06.104

White, P.J., and M. R. Broadley, 2003. Calcium in plants. Ann. Bot. 92, 487-511. https://doi.org/10.1093/aob/mcg164

\section{IZVLEČEK}

Namen raziskave je bil proučiti razporeditev esencialnih elementov kalcija ( $\mathrm{Ca}$ ), magnezija $(\mathrm{Mg})$, fosforja (P) in žvepla (S) v tkivih zrna tatarske ajde s tehniko mikro-PIXE (z delci inducirana emisija rentgenskih žarkov), ki omogoča kvantitativno analizo elementov z ločljivostjo enega mikrometra. Kemijska priprava zrna pri tehniki mikro-PIXE ni potrebna. Največje koncentracije Ca smo izmerili v luski, v kateri sta bili jasno vidni dve s Ca bogati plasti. Magnezija, P in S je bilo največ $\mathrm{v}$ kličnih listih in $\mathrm{v}$ tkivih embrionalne osi. Ker lahko razporeditev $\mathrm{P}$ in $\mathrm{S}$ uporabimo kot oceno razporeditve fitatov in beljakovin, sklepamo, da je s P in S bogat tanek sloj, ki obdaja celotno zrno in je jasno viden predvsem na delu, kjer meji na endosperm, v bistvu sloj alevronskih celic, v katerih so prisotni fitati in zlasti beljakovine. Kvantitativne informacije o prostorski porazdelitvi mineralnih elementov v zrnu so koristne pri razvoju tehnološke predelave zrnja in pri zagotavljanju zmanjšanja izgube mineralnih elementov med mletjem. 